\title{
The Euro Area After Another Crisis Summit: Ignore the Elephant in the Room at Your Peril
}

The special summit of heads of state in the euro area on 21 July has yet again averted the imminent default of a member state. As usual, it was a last-minute deal that meets the country's financing needs against the promise of fiscal consolidation, structural reform and privatisations. The second programme for Greece foresees less harsh lending terms, and these will also be extended to Ireland and Portugal. For instance, interest rates come down to those of the Balance of Payments Facility for non-euro member states, currently 3.5 per cent. The long maturity of minimum 15 years and up to 30 years, with a ten-year grace period, amounts to a restructuring of these countries' debt burdens, admitting that Greece is insolvent and the other two would become insolvent at the punishing terms initially granted. All eyes were on Greece, but this was also a statement about the precariousness of the Irish and Portuguese situation.

On the back of the stabilisation programme and debt restructuring, the summit again introduced "a raft of measures", as the official Commission website calls it, that are important beyond combating the immediate crisis. These institutional reforms make the European Financial Stability Facility (EFSF) and its successor, the European Stability Mechanism (ESM), more like the IMF. These financing mechanisms now have a flexible credit line and can act preemptively and use their resources to recapitalise banks or to intervene in secondary markets if exceptional circumstances so require. For the latter, both the European Central Bank (ECB) and the EFSF/ESM members have to give their unanimous consent. At first sight, the ECB has one-sidedly gained power over a facility backed by fiscal authorities. But the provision also binds the central bank. It establishes that the ECB is and remains the lender of last resort to the financial system, or more bluntly: member states will not let the Bank off the hook. The experience over recent months makes it very likely that the ECB will approve financial market interventions by the EFSF/ESM more often than the member states allow the facility to engage in. Member states can thus effectively force the ECB to intervene.

It remains to be seen how robust these innovations will prove in economic terms. The debt relief for Greece amounts to 21 per cent of its net present value including the "voluntary" contribution from the private sector. This is less than most experts believe necessary. After an initial sigh of relief, financial market actors seemed to have second thoughts already on Monday if spreads on Italian and Spanish bonds are anything to go by. But then financial markets have proven to be capricious and unreliable judges of all things macroeconomic: they were exuberant about the harsh austerity programme of the Irish government in August 2009 while any student with some Econ 101 exposure could anticipate that this must send the country into deep recession. When growth rates did turn more negative, the financial markets promptly took against Ireland, sending it into even deeper recession. Consequently, heads of state are no longer willing to accept that those who wrecked public finances by pushing the world into recession back in 2008-09 keep on preventing them from getting back on a sustainable path. The summit authorised the Commission (in para 15) to explore ways in which the EU regulatory framework can make itself less dependent on external credit ratings, which have proven to be conduits for the herding behaviour of private actors that leads to self-fulfilling crises.

If member states have little to go on other than the support they can give each other, how robust are these innovations in political terms? It is important to note what the summit conclusions imply for the political dimension of monetary integration. At the July summit, we got the IMF-type solution that Daniel Gros and Thomas Meyer proposed back in February 2010. The summit put an end to the anomaly that EU countries that are not in the euro area, like Hungary 
or Poland, got more lenient terms for their stabilisation programmes than the members of the monetary union. Even so, the policy conditionality in return for lending is stricter and more intrusive in either case than what the IMF would have advocated. The Fund abandoned detailed stipulations regarding structural reforms after extensive evaluations during the directorship of Horst Köhler had shown unequivocally that policy reforms imposed from outside do not take hold.

Seen in this light, the summit was a rather sobering event. Sure, governments now face up to the fact that some of their member states may partially default on their debt and that this may have fiscal costs for the guarantors. But this is the solidarity that each of the members has already implicitly extended to other nation states through the IMF. And for many guarantors it is not so much solidarity as enlightened self-interest, since it allows them to pool the risks for their banks and their export industries. But if the new arrangements do not go beyond the IMF on the principle of (potential) fiscal obligation and if major guarantors have good reason to help their euro area neighbours, why has it taken them so long to get to this point?

The elephant in the room where all these negotiations take place is democracy. In a standard IMF programme, the clever technocrats from Washington DC can comfort themselves that their intervention helps the disadvantaged silent majority in regimes that are usually run by clientelistic or outright authoritarian administrations. It is also a hegemonic intervention in which it is clear that the government receiving support is not an equal partner. This comforting fiction cannot be maintained in the EU. Democracy makes all the difference in at least three respects. First, the Council asks Papandreou to push programmes dictated in Brussels through a parliament that was not invited to the table. Second, Merkel must go back and tell her own backbenchers that they should agree to what she had previously promised would not happen when she played to the galleries in order to strengthen her hand in the negotiations in Brussels. Last but not least, the troika of Commission, IMF and ECB is a thin veil over what is perceived as the direct rule of some member states into other member states - this perception makes the Greek opposition even stroppier while it calms down Merkel's backbenchers.

This third aspect indicates that the political problem is more profound than just electoral politics: the guarantor countries took so long to subscribe to a European version of the IMF because they mistrust not only the government but also the people. Ironically, they trust the Papandreou administration more than the Greek population when they see demonstrations against cuts in pensions or the abolishment of taxi licences. It is understandably even worse in Italy, where they trust at best some technocrats like Tremonti and Bini Smaghi in the Treasury and the central bank respectively, but know that both command respect rather than influence in Italian politics.

This mistrust in other democracies suffers from short memory. The post-war consensus in Europe was built on the insight that economic security and democracy are linked. Franklin D. Roosevelt summarised it in one sentence: "People who are hungry and out of a job are the stuff of which dictatorships are made." Neither famine nor dictatorships are imminent. But democracies do not perform well when jobs disappear; and they are certainly not good at sustaining austerity over an indefinite time horizon. But this is exactly what EMU membership imposes on Greece and Portugal. Member states must be careful not to create a self-fulfilling prophecy. In the end, the elephant in the room may squash, if not crush, the euro. The fate of the ECB has shown that elected governments are ready to sacrifice the independence of the central bank if the going on bailouts gets tough. A squeeze of the euro for the sake of democracy is even an optimistic scenario. But it would be better still if Germany et al. could show more generosity so that both can flourish. 